\title{
THE CHOICE... LET US CONTINUE
}

When the returns came in the decision was massive. However one analyses and evaluates, how: ever one argues about the motives which led the citizens of the United States to decide as they did, the conclusion is inevitable: the voters repudiated the philosophy of that section of the Republican party for which Senator Goldwater was the spokesman; they chose to maintain in office President Lyrdon Johnson who said that he would continue the policies of the KennedyJohnson administration.

The presidential election of 1964 was important for a number of reasons and set records that will probably stand for some time. It will be pointed out, for example, that President Johnson was elected by a greater plurality of votes and by a higher percentage of votes cast than was any other president; that the deep South went Republican, Georgia for the first time; that, to match Georgia, Vermont for the first time, went Democratic; that Negroes gave Johnson a higher percentage of votes than any minority group had given to any previous candidate; that the amount of ticket splitting was very impressive in some sections of the country. From these and other characteristics of unegual value the analysts will attempt to squeeze out every last legitimate inference. Nothing, however, will alter the single large conclusion: what has long been regarded as a major "conservative" challenge has been rejected in favor of current thinking on domestic and foreign policies.

In the generally obfuscating atmosphere of the campaign one could discern three areas that promised, intermittently, to become the focus for informative debate. The first was the role of the government in dealing with the various problems of domestic society. What is the role of the federal government-relative to regional and local government and to the individual-in the areas of education, employment, housing, health, civil rights? What are the duties, what are the limitations? The various complexities of what are, after all, difficult problems went largely unexamined.
The public education that the campaign might have provided must yet be carried on.

The second large area concerned our foreign policy. Questions of foreign policy are assuming ever greater importance in our national elections and one could argue that if the results of the 1964 elections turned on any single matter it was this. Not particular issues, of course. That was not the nature of the campaign. The various particular questions resolved themselves, as far as the candidates were concerned, into the single question of the attitude this country should take toward communism. Should we pursue the policies that have been developed in the last several decades, or should we change our policies for more rigid, less accommodating measures?

The third area involved the complex and admittedly elusive relations between morality and politics. However lavishly squandered the opportunity, one must give credit to Senator Goldwater for introducing into the national campaign matter for serious debate. But this, too, remains an area in which there is need for much public education-indeed, public and official education.

In Dickens' Dombey and Son a Major Bagstock shows up on the scene bringing promises of renewal and change. But after a short period of exposure to the Major another character remarks, "If he's a change, give me a constancy." The incident has obvious application to the 1964 presidential election. But it also points up some of the anomalies of the election. There were, apparently, a large number of people whose vote was less for Johnson than it was against Goldwater. Since the campaign was, on the whole, a dreary and unedifying experience, there was little real debate on programs or issues. What were pitted against each other were large competing philosophies of government. But no philosophy of goveming, however triumphant in the balloting, can be applied like a mustard plaster to the various political ills that beset us. The ap- 
plication is a matter for close examination and hard decision.

Now that Lyndon Johnson has been given an overwhelming mandate, and can speak both at home and abroad with the confidence of that mandate, there is no reason for not moving as vigorously as decision permits.

At home the measures that have been on the agenda for some time include aid to education, medicare, the anti-poverty program and civil rights. The conservative bloc which blunted when it did not shatter many of President Kennedy's proposals has been much reduced. With this changed Congressional structure, the legerdemain so frequently conceded to the President should be remarkably effective.

While the domestic problems of this country are urgent, the averuses to their solution seem to have opened. The same cannot be said of some of our foreign policy problems. Our present policy in South Vietnam has been continued because any other-withdrawal or increased commitment and military engagement-appeared less desirable and because there was the hope that time would change some conditions of the problem. The conditions have changed but not to our advantage. A steadily deteriorating position must inevitably force another course of action.

In the same area of the world China has become, as anticipated, an even sharper problem. Our decisions regarding South Vietnam cannot easily be made apart from decisions concerning China, For what we do in Vietnam can either invite or inhibit China's expansionist tendencies, and although China does not now have an effective nuclear force, that too must be anticipated.

On the other side of the world, our relations with our NATO allies are in serious disrepair. The problems are posed most sharply by France, which has been challenging U.S. dominance for sorne years now. The most recent challenge is to threaten that if the U.S. pushes through with its plan for the MLF (multilateral nuclear force) and persuades Germany to join, then France will withdraw from NATO. The MLF presents England, too, with some hard choices to make; although the new Prime Minister shows a willingness to make decisions, the negotiating may be extended. But the controversy over the MLF, however it is resolved, has revealed some of the widening fissures in the alliance. How these are to be mended, bridged or accepted will be the substance of our policy discussions for some time.

$\bullet$

The ethics of individual political leaders has often been questioned in our country and in the heat and violence of campaigns the charges have often been fearsome. But the charges were made with some difference in this campaign. It was not simply a matter of saying, "Throw the rascals and scoundrels out." The attempt was made, however ineptly, to show some kind of relation between an administration and a supposed state of morality-or, more properly, immorality-in the country. This blunderbuiss charge did not allow the discrimination that is necessary before a discussion concerning ethics and policies can be enlightening.

In the article-review that appears in this issue, Michael Novak calls attention to the ground rules for such a discussion. Because we believe that it is too important a topic to be left in the dismembered state to which the campaign reduced it, we will return to it in future issues of worldview. The difficult task, which we will persuade some of our contributors to undertake, is to show how such debate is related to the many problems that the Johnson administration must face.

Note: worlduiew will soon complete its seventh year of publication. During these years the journal has presented the views of many distinguished writers in American life, often taking issue with one another. Among the contributors are Hans J. Morgenthain, John C. Bennett, Arthur A. Cohen, Michael Harrington, Gordon Zahn, John Courtney Murray, S.J., Steven Schwarzschild, Thomas Molnar, Paul Ramsey, Will Herberg, John Cogley, Paul Nitze, Harlan Cleveland, Philip E. Mosely. During these years the journal has reached an increasingly wide range of readers, but for the magazine to be most effective a much wider readership must be developed. For this we must depend, in large part, on those who now subscribe. We therefore urge our present readers to consider presenting gift subscriptions to friends who they think will be interested in worldview. For this purpose the holiday gift subscription blank appears on page ten of this issue. But a simple note with the names of the recipients will also be sufficient. 